\title{
INVESTIGATION OF STUDENTS' BEHAVIOR IN MATHEMATICAL PROBLEM SOLVING
}

\author{
Yulyanti Harisman ${ }^{* 1}$, Muchamad Subali Noto ${ }^{2}$, Wahyu Hidayat ${ }^{3}$ \\ ${ }^{1}$ Universitas Negeri Padang, Indonesia \\ ${ }^{2}$ Universitas Swadaya Gunung Jati, Indonesia \\ ${ }^{3}$ Institut Keguruan dan Ilmu Pendidikan Siliwangi, Indonesia
}

\begin{tabular}{l}
\hline \hline Article Info \\
\hline Article history: \\
Received May 28, 2021 \\
Revised July 1, 2021 \\
Accepted July 2, 2021
\end{tabular}

\section{Keywords:}

Behavior,

Naïve,

Problem solving,

Routine,

Semi-Sophisticated,

Sophisticated

\begin{abstract}
This study is a qualitative research by using the descriptive method that aims to examine the behaviour of eighteen students in Bandung, Indonesia. Six issues related to geometry were given to eighteen of second-grade junior high school students with heterogeneous abilities. The problems given to the students contained all of the problem-solving strategies such as guessing and checking, make a picture, make a list, make a table, working backwards, looking patterns, and using a logical reason, solving simple problems and making questions. Data collection was conducted through mathematical problem-solving tests, recording students' presentations, and interviewing among researchers and students after doing the problems. The result of recording was a video during the presentation process, and the interview would explore their understanding of the given problems to see the behaviour used by subjects of the research. The data in this research showed that many students' behaviour identified; in the relevant literature, there are terms of the behaviour of problem-solving naive, routine, and sophisticated. However, the category "naïve," "routine," and "sophisticated" did not fully draw various behaviours observed, it was obtained additional category termed behavioural problem solver "naïve," "routine," "semi-sophisticated" and "sophisticated". It was due to the category of regular students can be divided into two, some students can be directed, and some of them cannot be directed to sophisticated behaviour. Thus, the routine category can be classified into two categories: routine and semi-sophisticated.
\end{abstract}

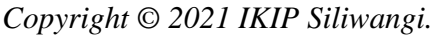
All rights reserved.

\section{Corresponding Author:}

Yulyanti Harisman,

Departement of Mathematics Education,

Universitas Negeri Padang

Jl. Prof. Dr. Hamka, Air Tawar, Padang City, West Sumatra 25171, Indonesia

Email: yulyanti_h@fmipa.unp.ac.id

\section{How to Cite:}

Harisman, Y., Noto, M. S., \& Hidayat, W. (2021). Investigation of students' behavior in mathematical problem solving. Infinity, 10(2), 235-258.

\section{INTRODUCTION}

The curriculum of Mathematics education in Indonesia has changed several times. The changes were enacted curriculum starting from 1947 until 2013. The 2013 curriculum applies nowadays, insists on the importance of thinking skills, communication, and a deep understanding of students in solving problems encountered in the learning process of mathematics, therefore it is necessary to change the curriculum. 
Regulation of the Minister of Education and Culture (PERMENDIKBUD) No. 22 the year, 2016 about the standard of primary and secondary education, stated that the skills acquired through the activity of "observing, asking, trying, reasoning, presenting, and creating." Characteristics of competence and the difference of acquisition affect the process standard characteristics (MECRI, 2016). To encourage the ability of learners to generate contextual work, either individually or in groups, are strongly suggested to use learning approaches that produce project-based learning. It appears that the standard process of primary and secondary education in the curriculum also emphasizes on solving mathematical problems (Chew, Shahrill, \& Li, 2019; Olivares, Lupiáñez, \& Segovia, 2021; Stacey, 2005).

The studies conducted by experts mostly focus on the effective implementation of teachers to improve the abilities and behaviour of students in solving problems. A study conducted by Hidayat (2017) examine the problem-solving behaviour of senior high school students on non-routine problems associated with the concept of calculus material. Another study also examined the implementation of teachers conducted by Sulak (2010), which saw the effects of problem-solving strategies towards the achievement of problem-solving in primary school students.

Furthermore, Cai (2003) did an international study that documented the problemsolving approach, which covers most of the students, describing the successful implementation problem-solving approach in learning mathematics. Besides the studies evaluating the implementation of teachers' strategies to improve students' problem-solving, several studies also investigated how the approach used by students in solving problems. The research had done by De Hoyos, Gray, and Samson (2002) that observed the processes carried out by two students in solving the problem. Muir, Beswick, and Williamson (2008), "Although there have been studies that see the approach of the students, there is no effort of researchers to verify whether the selected students are consistent in any issue."

Muir et al. (2008) conducted a study that saw the consistency of behaviour that he selected 20 elementary school students from 5 different schools in solving problems. This study has six questions which contain various strategies proposed by Polya (1957). A research conducted by Muir et al. (2008) was grounded on research from Schoenfeld (1982), which examined how a problem-solving expert and novice choose behaviours that were used in solving the problem.

According to Schoenfeld (1982), behaviours selected by an expert in solving the problem are: the expert on problem-solving tend to recognize the patterns of problems, tends to change strategy when a strategy is not working, and an expert on problem-solving can generate its strategy in solving problems. Furthermore, some of the behaviour displayed by novice problem solvers in solving the problem is: only recognize the problem of the surface of it, tend to manipulate numbers in solving problems, and unable to move strategy if a strategy does not work (Harisman et al., 2019)

The research findings of Muir et al. (2008) complemented the research done by Schoenfeld (1982). If Schoenfeld categorized the behaviour of students when solving problems in two categories, namely expert and novice, then Muir et al. (2008) categorized it into three categories: naive, routine, and sophisticated. Naive behaviour-oriented on problem solver behaviour associated only with manipulating numbers that exist in the problem. Routine behaviour-oriented on structured behaviour and sophisticated problem solvers oriented on problem solver who can generate their strategies when they faced problems (Harisman et al., 2020). 


\subsection{The process of problem solving}

Talking about solving mathematical problems certainly will not be released from the core problem itself. Problems solving questions are usually non-routine problems. Problemsolving also related to other terms such as reasoning, critical thinking, creative thinking, decision-making is a subset of problem-solving (Ekawati et al., 2020; Hendriana \& Fadhillah, 2019; Hutajulu et al., 2019; Kariadinata, 2021; Maulidia et al., 2019; Praekhaow et al., 2021). Through problem-solving, it will broaden a person's thought, from which he does not know transform into he knows when carrying out the process of solving the problem.

According to Elia, van den Heuvel-Panhuizen and Kolovou (2009), in answering the questions of problem-solving, we can use flexible strategies, and they can be modified and changed if the strategies do not work. Besides, using problem-solving strategies require several abilities include interpreting information, planning and working methods, checking the results, and trying to look for an alternative strategy (Muir et al., 2008).

Heuristic planning most recommended by researchers (e.g., Schoenfeld, 1982) to facilitate the resolution of the problem is coming from Polya (1957) and requires the problem solver to understand the problem, set a plan, implement the plan, and check back the solution which has been obtained, Polya (1957) further explained in How to Solve It as outlines shows four main steps in solving the problem, they are: Understanding the problem, Devising a Plan, Carrying out the Plan, and Looking Back.

Heuristic and strategies identified are most widely used in problem-solving, guessing and checking, making an image, creating a list, tables, working backwards, seeing patterns, and using a logic reason, solving simple problems and making questions (Muir et al., 2008). Based on the indicators outlined in the Polya (1957), it created a rubric that will be used to check the students' work in solving the problems (see Table 1).

Table 1. Problem solving ability scoring rubric (Muir et al., 2008)

\begin{tabular}{clll}
\hline \multirow{2}{*}{ Scores } & \multicolumn{3}{c}{ Problem Solving Ability Rubric } \\
\cline { 2 - 4 } & \multicolumn{1}{c}{$\begin{array}{c}\text { Understanding the } \\
\text { problem }\end{array}$} & \multicolumn{1}{c}{ Devising a plan } & $\begin{array}{c}\text { Carrying out the } \\
\text { plan }\end{array}$ \\
\hline 0 & $\begin{array}{l}\text { Unable to identify the } \\
\text { information that exists in } \\
\text { the problem }\end{array}$ & $\begin{array}{l}\text { Not using one of the } \\
\text { problem-solving strategies }\end{array}$ & $\begin{array}{l}\text { Loading errors in } \\
\text { every step of the } \\
\text { completion }\end{array}$ \\
1 & $\begin{array}{l}\text { Able to identify the } \\
\text { information contained in } \\
\text { the problem }\end{array}$ & $\begin{array}{l}\text { Using problem-solving } \\
\text { strategies but contains } \\
\text { wrong steps }\end{array}$ & $\begin{array}{l}\text { There are errors in } \\
\text { several steps to } \\
\text { resolve }\end{array}$ \\
2 & $\begin{array}{l}\text { Understanding the } \\
\text { meaning of every } \\
\text { information in the } \\
\text { problem }\end{array}$ & $\begin{array}{l}\text { Using problem-solving } \\
\text { strategies with the right } \\
\text { steps }\end{array}$ & $\begin{array}{l}\text { There are no errors } \\
\text { in every step of } \\
\text { completion }\end{array}$ \\
\hline
\end{tabular}

Based on these rubrics, students' work will be analyzed, and during problem-solving, it will be seen the consistency of students' problem-solving behaviour. Many things can affect the performance of solving the problem; one of them is effective. Several dimensions of affective that affect problem-solving are emotion, the level of awareness, and control of students (McLeod, 1988). Fitzpatrick (1994) examined the relationship of various cognitive factors, attribution, and gender in finding the solution of a mathematical problem solving 
with 100 SMU. Based on these other aspects need to be examined outside the problemsolving process mentioned by Polya (1957), which becomes the main reference in this article. Things that affect performance problem solving outlined in problem-solving behaviour. Besides, students' ability to solve their behaviour problem, it also needs to see the weaknesses of them in solving problems. Below are descriptions of behaviours that indicate to students in solving problems through observation of research experts' findings.

\subsection{The behaviour of problem solving}

Behaviour is a response to the stimulus given to the students. The behaviour can be measured and observed through observation. If people are in a situation of containing the problem, then the individual will show a course of conduct to solve the problem. The mathematics learning process often exposes students to the issues of problem-solving. To solve these problems, of course, the student will show a set of behaviours. Most of the researchers focus only on tests of mathematical problem solving, but this approach has been criticized because it is not sufficient, because the tests do not provide information about how students think (Fitzpatrick, 1994). In order for researchers not only focus on the test and see things other than the investigator should observe the behaviour of students in solving the problem.

There have been studies on mathematics education that examined students' behaviour in facing problems solving. Schoenfeld (1982) researched how problem-solving expert and novice problem solvers behave in solving problems with student research subjects in colleges. Through these studies, Schoenfeld found that the novice problem solvers tend to exhibit behaviour in recognizing the problem only from the surface, while the expert problem solvers show their behaviour in recognizing the pattern of these problems. The novice problem solver tends to manipulate the numbers on the issue, read quickly and at a glance, do not give consideration to the context of the problem, not diligent in resolving the problem if the chosen strategy does not work, do not access other problem-solving strategies, do not show thinking metacognitive. The experts tend to exhibit their different behaviour to manage the problem better, motivated intrinsic and high curiosity, like the challenge, always work actively, always recheck the solution that has been obtained, explore more to find alternative solutions

Muir et al. (2008) also viewed behaviour that indicated 20 elementary school students in solving problems. According to Muir et al. (2008), experts and new problem solvers do not accommodate the behaviour intended to show. The rubric of problem-solving behaviour after twenty students worked on six problems solving and conducted interviews with them (see Table 2).

Table 2. Overview of students' behaviour based on a range (Muir et al., 2008)

\begin{tabular}{clll}
\hline \multirow{2}{*}{ Factors } & \multicolumn{3}{c}{ Category of Behaviors } \\
\cline { 2 - 4 } & \multicolumn{1}{c}{ Nä̈e } & \multicolumn{1}{c}{ Routine } & \multicolumn{1}{c}{ Sophisticated } \\
\hline Knowledge & $\begin{array}{l}\text { Making mistakes on } \\
\text { Ownership } \\
\text { the four-step problem- } \\
\text { solving }\end{array}$ & $\begin{array}{l}\text { There is no attempt to verify } \\
\text { the solution (Making } \\
\text { mistakes at some problem- } \\
\text { solving steps) }\end{array}$ & $\begin{array}{l}\text { A high score on } \\
\text { every step of } \\
\text { problem-solving }\end{array}$ \\
\end{tabular}




\begin{tabular}{|c|c|c|c|}
\hline \multirow{2}{*}{ Factors } & \multicolumn{3}{|c|}{ Category of Behaviors } \\
\hline & Naïve & Routine & Sophisticated \\
\hline & $\begin{array}{l}\text { Unable to use the } \\
\text { earlier problems that } \\
\text { have been resolved }\end{array}$ & $\begin{array}{l}\text { Able to identify similar } \\
\text { issues, but not on the } \\
\text { mathematical structure }\end{array}$ & $\begin{array}{l}\text { Identifying similar } \\
\text { problems in the } \\
\text { structure of the } \\
\text { mathematics }\end{array}$ \\
\hline & $\begin{array}{l}\text { Frequent use the same } \\
\text { way to solve all } \\
\text { problems }\end{array}$ & $\begin{array}{l}\text { Focus on one way to solve a } \\
\text { particular problem. }\end{array}$ & $\begin{array}{l}\text { Identifying other } \\
\text { ways to solve the } \\
\text { problem }\end{array}$ \\
\hline & $\begin{array}{l}\text { Written } \\
\text { communication and } \\
\text { verbal are not } \\
\text { sufficient }\end{array}$ & $\begin{array}{l}\text { Verbal communication is } \\
\text { usually clear }\end{array}$ & $\begin{array}{l}\text { Written } \\
\text { communication } \\
\text { and verbal are } \\
\text { adequate }\end{array}$ \\
\hline Controls & $\begin{array}{l}\text { Thinking } \\
\text { metacognitive does not } \\
\text { appear, either in } \\
\text { written communication } \\
\text { and verbal }\end{array}$ & $\begin{array}{l}\text { Thinking metacognitive } \\
\text { looked verbally }\end{array}$ & $\begin{array}{l}\text { Thinking } \\
\text { metacognitive is } \\
\text { clear in response } \\
\text { to written and } \\
\text { verbal }\end{array}$ \\
\hline \multirow[t]{2}{*}{ Confidence } & $\begin{array}{l}\text { Doing almost the same } \\
\text { strategies }\end{array}$ & $\begin{array}{l}\text { Implementing strategies in a } \\
\text { systematic way }\end{array}$ & $\begin{array}{l}\text { Generates its } \\
\text { strategy }\end{array}$ \\
\hline & $\begin{array}{l}\text { Relying on one or two } \\
\text { strategies }\end{array}$ & $\begin{array}{l}\text { Relying on more than two } \\
\text { strategies, but can not move } \\
\text { to another strategy when a } \\
\text { strategy can not work }\end{array}$ & $\begin{array}{l}\text { Willing to use a } \\
\text { combination of } \\
\text { several strategies }\end{array}$ \\
\hline Affective & $\begin{array}{l}\text { Confidence is in line } \\
\text { with a quick } \\
\text { achievement answers }\end{array}$ & $\begin{array}{l}\text { Often express lack of } \\
\text { confidence in the ability to } \\
\text { solve problems }\end{array}$ & $\begin{array}{l}\text { Reveals } \\
\text { confidence in the } \\
\text { ability to solve } \\
\text { problems }\end{array}$ \\
\hline
\end{tabular}

The rubric (see Table 2) based on things that affect the behaviour presented by Lester and Kroll (1993). According to Lester and Kroll, problem-solving performance is affected by five factors: acquisition knowledge and utilization, control, confidence, affective, and socio-cultural context.

\subsection{Statement of the Problem}

The implications of the research findings from Muir et al. (2008) state that "a decision of this behaviour that has an impact on studying and learning of solving the problem". After analyzing the behaviours that are shown by Muir et al. (2008), the authors interested in conducting the study in secondary schools in the city, Bandung. Particularly, it addresses the following qustions: (1) What behaviours are shown by some secondary high school students in the city of Bandung, Indonesia? (2) How far is the consistency carried out by each student? The selected subject is geometry based on the experience of junior high school teachers who explained that students have difficulty in understanding the material. 


\section{METHOD}

\subsection{Description of study}

This study was conducted to see the behaviour of eighteen from three different junior high school students in the city of Bandung in solving problems. The study was based on a study done by (Muir et al., 2008) where it will be seen how all knowledge of Ownership, Control, Confidence, and Affective of students when they were given problem-solving questions. Muir et al. (2008) saw it on elementary students in Tasmania. The researcher would like to try to do this on a junior high school in Bandung city.

\subsection{Participants}

Subjects in this study were eighteen students in three junior high schools in the city. Students were selected with varying capabilities (high, medium, and low). The ability of students viewed from the midterms that were given by teachers. The students were chosen because they considered in the transition of the period from children to teenagers. It was expected that the behaviour they appear would be more expressive and spontaneous. It was expected that strategies would be more informal displayed by students. Junior high school students are considered students who will be at the level that will bring a model of solving problems that will show models for the solution of such problems.

\subsection{Assessment instrument}

The task given to the students was the problem solving that contained all the problem-solving strategies. The problem was designed to be seven questions. Seven problems raise a wide variety of strategies that will have students like to make a list, a portrait of the diagram, see patterns, and so on. This matter has also been used in studies of observing gesture gender with different students in solving problems (Harisman et al., 2017). Selected Topics in this study was the topic of geometry. This topic was chosen according to the junior high school teaching experience. The students often have difficulties when they are faced with the problems of geometry (see Table 3).

Table 3. Description of the problems

No Description of the problems

1 Mr Hok Guan, the owner of the pipe shop, wants to tie his pipes with rope, each bond is six pipes. He is confused about how to tie them $(r=10 \mathrm{~cm})$. Is the model bonding a rectangular or triangular model? Because the rope used to tie the pipes is limited, Mr Hok Guan expects more efficient use of the rope. Help Mr Hok Guan to solve the problem. Which binding is the most economical?

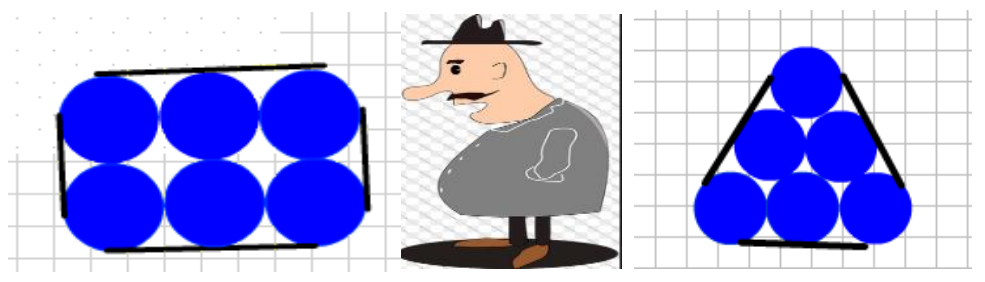




\section{No Description of the problems}

2 Here are cube nets that are numbered 1 through 6 . What is the largest of three numbers on the sides, which together form the cube-corner point?

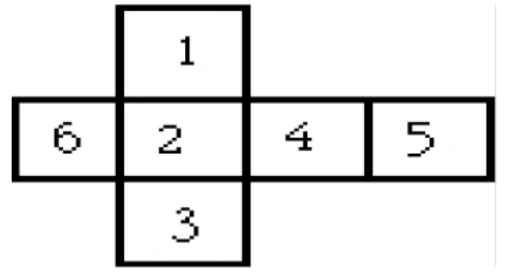

3 It is known that a swimming pool with a pool size of 60 meters long, 15 meters wide, depth of 1 meter left hand and kept right ramps up to a depth of 5 meters. Calculate the volume of water needed to fill the pool to the brim.

4 Pay attention to the unit cube pile below. If the unit cube pile pattern continues, what is the number of the unit cube on stacks to-5?
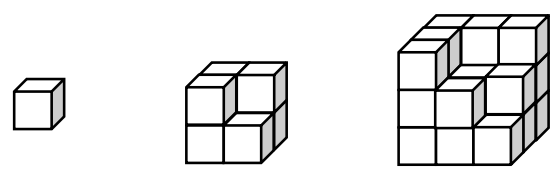

5 It gives a square $\mathrm{ABCD}$ with a side length of 2 units. The sides of the square are the radius of the circle. Calculate the area shaded?

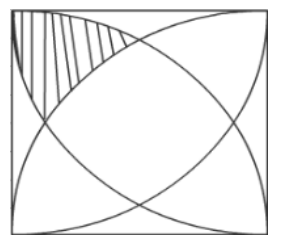

6 Mr Ahmad wants to include several books of the same size, namely: length 20 $\mathrm{cm}$, width $15 \mathrm{~cm}$, and $2 \mathrm{~cm}$ thick in a box-shaped beam with a size of $30 \mathrm{~cm} \mathrm{x} 25$ $\mathrm{cm} \times 25 \mathrm{~cm}$. What is the maximum number of books that can be inserted into the box?

7 The volume of a cube is equal to the volume of a beam that is. It is known that the long beam twice as long as high-beam cube and half times the width of the beam. Determine the whole surface area of the beam!

After the eighteen students asking to answer seven problems above, they were interviewed about the answers to the questions submitted. Students were asked to respond to these questions while the interviewee was recording and making observations notes of the interview process. The interview approach is called the semi-structural approaches interviewed by Burns (Muir et al., 2008). The students' answers were analyzed by using rubric existing sections in Table 4. 
Table 4. Problem solving capabilities scoring rubric (Muir et al., 2008)

\begin{tabular}{clll}
\hline \multirow{2}{*}{ Scores } & \multicolumn{3}{c}{ Problem Solving Ability Rubric } \\
\cline { 2 - 4 } & $\begin{array}{c}\text { Understanding the } \\
\text { problem }\end{array}$ & $\begin{array}{c}\text { Explaining the plan of } \\
\text { problem solving }\end{array}$ & $\begin{array}{l}\text { Checking back the } \\
\text { problem solving }\end{array}$ \\
\hline 0 & $\begin{array}{l}\text { Unable to identify the } \\
\text { information that exists in } \\
\text { the problem }\end{array}$ & $\begin{array}{l}\text { Not using one of the } \\
\text { problem-solving strategies }\end{array}$ & $\begin{array}{l}\text { Loading errors in } \\
\text { every step of the } \\
\text { completion }\end{array}$ \\
1 & $\begin{array}{l}\text { Able to identify the } \\
\text { information contained in } \\
\text { the problem }\end{array}$ & $\begin{array}{l}\text { Using problem-solving } \\
\text { strategies but contains } \\
\text { wrong steps }\end{array}$ & $\begin{array}{l}\text { There are errors in } \\
\text { several steps to } \\
\text { resolve }\end{array}$ \\
$\begin{array}{l}\text { Understanding the } \\
\text { meaning of every } \\
\text { information in the } \\
\text { problem }\end{array}$ & $\begin{array}{l}\text { Using problem-solving } \\
\text { strategies with the right } \\
\text { steps }\end{array}$ & $\begin{array}{l}\text { There are no errors } \\
\text { in every step of } \\
\text { completion }\end{array}$ \\
\hline
\end{tabular}

Data were analyzed with the mentally correct answer and ranked based on the scoring rubric listed in Table 4. Tally also conducted on how many strategies are chosen by students in completing the seven questions. Then, the data were analyzed to see the students' behaviour through the analysis of the results of the interviews.

\section{RESULTS AND DISCUSSION}

\subsection{Behavior Problem Solving}

Orientation students' behaviour of three junior high schools in Bandung is presented in this section. Six students were selected from each school with different abilities. Two students have a low capability, two students have the middle ability, and two students have a high ability. The students were recommended by school teachers based on mathematical ability. Students were labelled A to high-ability students, $\mathrm{S}$ for middle students, and $\mathrm{R}$ for lower-ability students. Furthermore, in labelling schools, S-1 is for the school one, S-2 for the school two, and S-3 is for school three. The following explanation is in Table 5 the names and abilities of students in each school.

Table 5. Name and ability of students at each school

\begin{tabular}{llll}
\hline \multirow{2}{*}{ No } & \multicolumn{3}{c}{ Student's school origin } \\
\cline { 2 - 4 } & \multicolumn{1}{c}{ School one } & \multicolumn{1}{c}{ School two } & \multicolumn{1}{c}{ School three } \\
\hline 1 & Lutfi (R) S-1 & Dwi Nanda (R) S-2 & Fauzan (R) S-3 \\
2 & Divy (R) S-1 & Aulia Fauza (R) S-2 & Rizky (R) S-3 \\
3 & Fikri (S) S-1 & Najla (S) S-2 & Mesya(S) S-3 \\
4 & Dhea (S) S-1 & Febrina (S) S-2 & Dita (S) S-3 \\
5 & Annisa (T) S-1 & Zara (T) S-2 & Yani (T) S-3 \\
6 & Alvaro (T) S-1 & Salma (T) S-2 & Nadhira (T) S-3 \\
\hline
\end{tabular}


Labelling is done to facilitate in grouping the students based on the behaviour category at the end grain. Rubric behaviour Muir et al. (2008), which presented in the previous section (Table 2), used as a reference early in categorizing the students' behaviour.

The description of data is only presented to students who are at the same school. For other schools also analyzed in the same way, but it is not described in the discussion. Recapitulation of the analysis results for each student in each school is included at the end of the description. The behaviour of mathematical problem-solving in each indicator of students at school (S-1) will be described - the names of the students: Lutfi, Divy, Fikri, Dhea, Annisa, and Alvaro. The following is an overview of students' behaviour in every aspect of mathematical problem-solving behaviour.

\subsection{Knowledge Ownership}

\subsubsection{Applying heuristics Polya step in mathematical problem solving}

Students' apathetic behaviour made a mistake on the four-step problem-solving. This is indicated by Fikri answer in solving two problems in Figure 1 at the following tasks in Table 3.

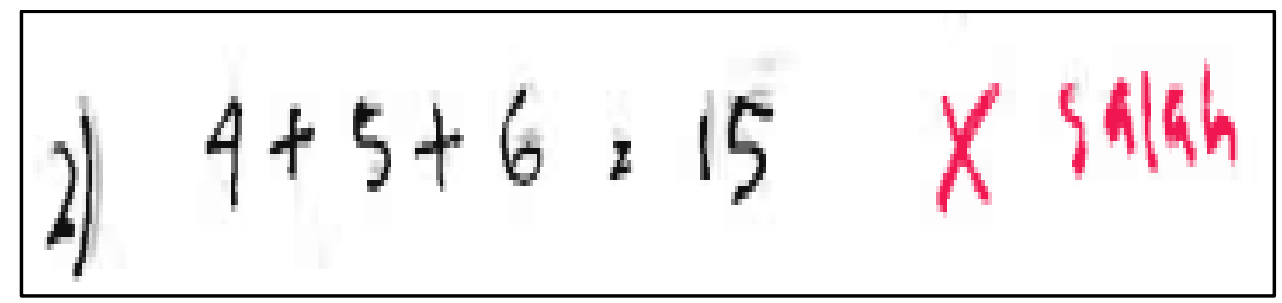

Figure 1. Representation of Fikri's mathematical problems two

Fikri did not understand the problem because Fikri did not know the purpose of the three sides that would form the vertices, Fikri has not been able to choose the right strategy and implemented it. Fikri supposedly tried-piloted three sides which will form the corner points then choose which of the numbers that are on the three sides if it is added together, it will result in big numbers. Problem two was designed with one strategy solution, they are guessing and check, but because Fikri did not understand the problems of the strategy selected, so the finding was not right, that only by choosing three numbers on the sides nets of the cube that when the nets were added together, it would produce the largest number, and Fikri has not made the resulting checking to the answer. The unreached comprehension, the wrong strategy selection, and implementation and has not been checked back into the solutions are also demonstrated through interviews with the following Fikri.

Interviewer : What is going with this?

Fikri : The biggest number is 4, 5 and 6

Interviewer : It is, but the problems are known here, nets of a cube. What are the cube nets?

Fikri :I do not know

Interviewer : Nets of a cube are a series of squares that belong to a two-dimensional figure if they are strung together back, they will form a geometrical cube, remember?

Fikri :Yes

Interviewer : Well, $l$ the things looked for is the biggest of three numbers, but which together form the corner points, now the question is whether the 6, 4, and 5 form a vertex? 
244

Harisman, Note, \& Hidayat, Investigation of students' behavior in mathematical problem ...

Fikri $\quad:$ I do not know

Interviewer : Try, for example; the base is two, then four, then six, then the roof is five, is it going to form a corner? Try to imagine!

Fikri $\quad$ : I do not know

Interviewer :(Taking a cube). Take a look, how is the pedestal?

Fikri :Two

Interviewer : Left?

Fir i: $\quad:$ Six

Interviewer : Right?

Fikri :Four

Interviewer : The roof?

Fikri : Lima

Interviewer : Now, are six, four, and five forms a corner?

Fikri :I do not know

Interviewer : Not form, which forms a corner that is part of this, this and this (pointing to three different sides that form the vertex). So, although the 6, 4, and 5 are the three largest numbers they do not form a corner point, it should be tried first one-on-one, can we imagine or not?

Fikri :Yes

Although Fikri has been directed to understand the problem and led to determine which three sides that will form the vertices, Fikri always replies with answer directives do not know.

Furthermore, students who behave routine behaviour shown by the representation and Dea's answer to problem number two, respectively, are as follows in Figure 2 and Figure 3.

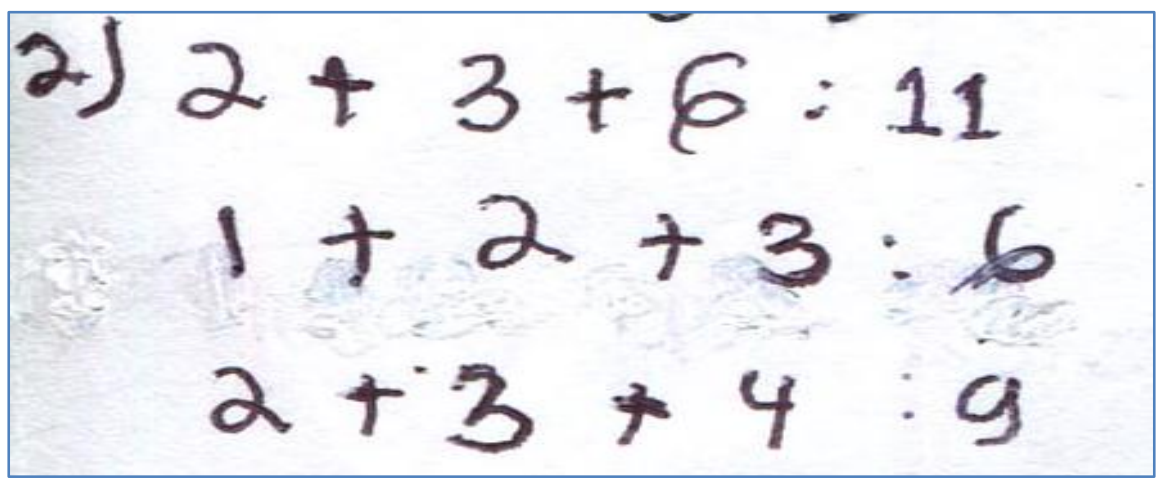

Figure 2. Representation of mathematical devi for problem two 


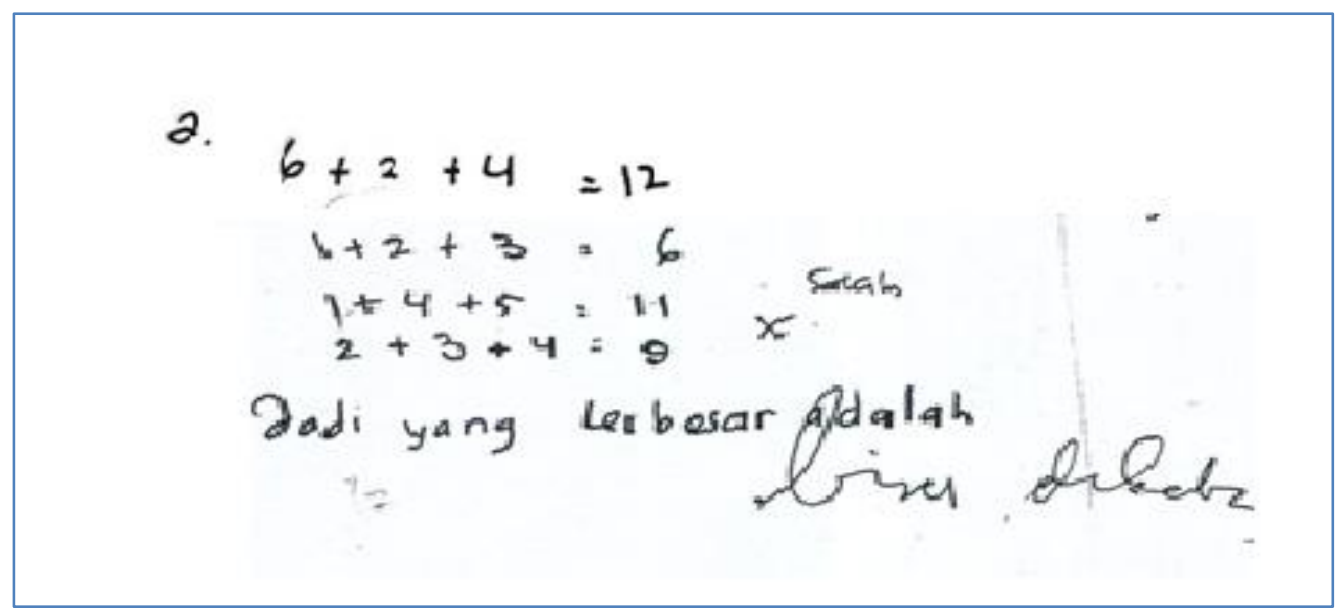

Figure 3. Mathematical representation of dhea for problem two

Based on the answers and interviews, Dyvi and Dhea understood the existed problems, in which they understood where the three numbers on the sides of the cube that would shape vertices. They were assumed that they already chose the right strategy, guess and check, three digits on the side that would form the corner points, but still had several steps to resolve the error and not presenting the correct answers yet. Dyvi was right in choosing three numbers that would form the corner points: 2, 3, 6 and 2, 3, 4, but she was still wrong in choosing the numbers $1,2,3$, and not presenting the correct answer which was not determined yet where the three biggest numbers that would form the corner points. Dhea was also right in choosing three numbers that would form the corner points: $2,3,4$, and 1 , 4,5 , but she was still wrong in choosing the numbers $1,2,3$, and 6, 2, 4, and Dhea also did not present the correct answer that was not yet determined where the three largest numbers that would form the vertices. The following interview on Dyvi and Dhea is presented below.

Interviewer : In question number two, what story is this? What is this?

Dyvi : Cube, oh yes nets

Interviewer : What is the net?

Dyvi : That is they are; it is hard to explain

Interviewer : Is it hard to explain it? So if the nets are folded they are going to form a cube Dyvi : Yeah, like that

Interviewer : Well, What would be asked now?

Dyvi : What are the three largest number sides together that will form a cube corner point?

Based on the result of the interview, Dyvi understood what was meant in the questions, but did not have enough knowledge to verify the solution. Dyvi assumed that what she did was correct. When she was directed that the three numbers written by Dyvi were wrong, Dyvi also did not attempt or desire to seek out the truth of the response. The following interview shows this:

Interviewer : (Take wake cubes), what number is in the base?

Dyvi :Two

Interviewer : How many are these? (pointing to the left side)

Dyvi : Six

Interviewer : How many are these? (pointing to the front side)

Dyvi : Three 
Interviewer : How much are these? (Referring to the right side)

Dyvi :Four

Interviewer : How many are these? (Referring to the rear side)

Dyvi : One

Interviewer : How many are the roof?

Dyvi : Lima

Interviewer : Okay, now what was just asked?

Dyvi : The biggest sum of three numbers

Interviewer : What three numbers did that mean?

Dyvi : The numbers that will form the corner; it was just correct; it was explained one by one.

Based on the interview above, Dyvi felt confident with her answers, and she had no attempt to verify the answers. The way of Dyvi's thinking in planning strategies have been passed Fikri that is still in the orientation behaviour of apathy, Dyvi did not only focuses on the numbers that exist in the questions, but had planned to try-piloted figures that would form the corner points, but there was still mistaken in several steps of problem-solving when the interviewer directed her, Dyvi did not show her effort to verify the mistaken answers.

The different things were shown by Dhea that was indicated by an effort to verify the answers. It can bee seen in the description of the interview below.

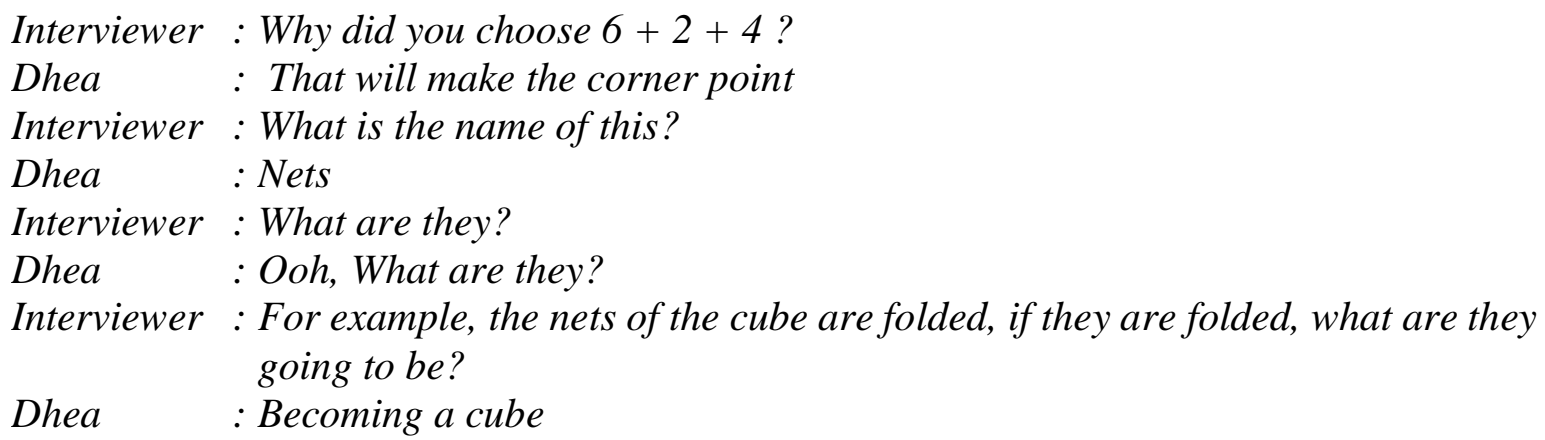

Dhea firstly was sure with her answers that the 6,2, and 4 sides would form the corner point, but, if it were re-check of the three sides, it would not form a corner point. Dhea already understood what the cube nets are, she planned the strategies well, but she still did a mistaken in executing the plan. When the interviewer directed her, Dhea showed her effort in verifying solutions on several steps of problem-solving that were still confusing. It can be seen from Dhea's responses below.

Interviewer : Interviewer point on one of the bases. By helping (geometry that forms a cube) the base is two, so what about the above?

Dhea :Five

Interviewer : Well, Now Which side is formed this corner point? (Pointing to one of the cubes)

Dhea : Left, front, and above Left, front, top

Interviewer : Yes, that is correct, what is the number?

Dhea : Six, five, and four

Interviewer : Why four? Try to see it again.

Dhea : Oh six, five, and three

Interviewer : Yes, Is there anything bigger? 6, 4, and 5 are the largest numbers, aren't they? 
Dhea : This six, five, and four have no corner points (pointing to the three sides on the cube)

Interviewer : So, why not six, four, and five?

Dhea : Because not form a corner point

When the researcher was directing that the sides chosen by Dhea would not form on the cube. Dhea could verify the incorrect answers she gave. Furthermore, when she was given another problem that is related to another one, Dhea was also able to explain it well. It can be seen from her answers that showed she did not choose the six, five, and four sides because the combination of the sides would not make a corner point. She showed an effort in verifying solution even though there was still found mistakes on steps of problem-solving. According to the case, Dhea passed the problem-solving behaviour category that was shown by Dyvi (routine) but cannot be categorized yet on sophisticated behaviour category (Muir et al., 2008).

The orientation of sophisticated behaviour category that was shown by Alvaro can be categorized as sophisticated behaviour because Alvaro already had a high score on every step of problem-solving. It can bee seen on the result of Alvaro's answer sheet for problemsolving number 2 in Figure 4.

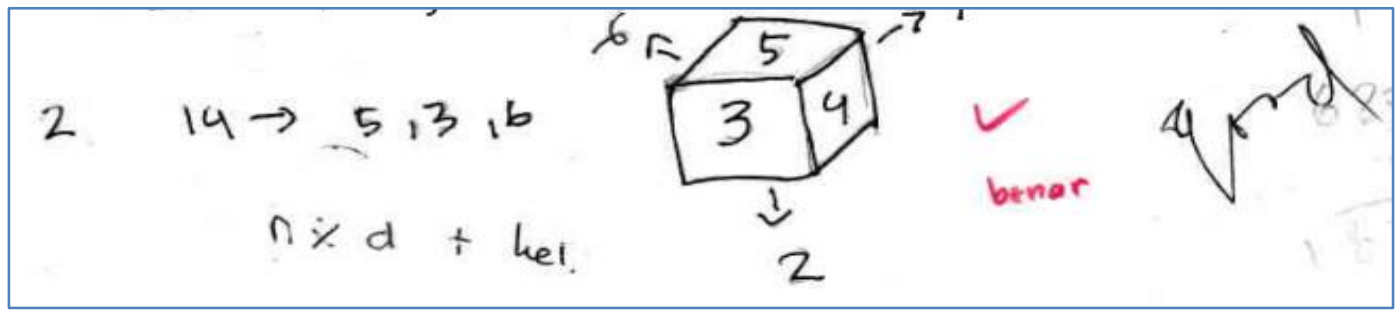

Figure 4. Representation of alvaro's mathematic for problem 2

Alvaro already understood the three biggest numbers that formed a corner point chose a right strategy by describing the nets of cube and put all of the numbers on the sides of the cube, and ran the strategy by choosing three biggest numbers which would form corner point, i.e. 5, 3, and 6, and also rechecked his answers. In the interview, Alvaro showed his well understanding of the problem. It can be seen in the description of the interview of Alvaro below.

Interviewer : Number two was correct, O.K? Why did you choose 5, 3, and 6 on this? Alvaro : Imagine! If this base is two, so the roof is five, and this one is three, this one is six on the left, and that is the biggest one. imagine this picture in your mind

Interviewer : Yes, that is correct

Based on Alvaro's answer, it shows that he understands the problem has a good strategy in doing it. The next is the description of students' behaviour category on indicators to two aspects of knowledge ownership as follow.

\subsubsection{Use previous knowledge for mathematics problems}

In using the previous knowledge to solve a mathematical problem, two terms should be understood. First, students can only connect the problem by seeing the figure, for example, only with remembering the formula or concept that are used in the problem.; 
second, students can connect the problem to see the mathematical structure, such by seeing the principles on formula or concept which is connected to the problem that the students face.

On the aspect of using the previous knowledge to solve mathematical problems, the apathetic students will show a behaviour that they cannot use the previous problem, which was over to solve a new problem. Fikri showed it. Almost all over the problems he always answered do not know and not remember when he was asked about whether he was ever given the same question before or not. Here is the answer of Fikri in an interview in solving problem one in Figure 5, Figure 6, and Figure 7.

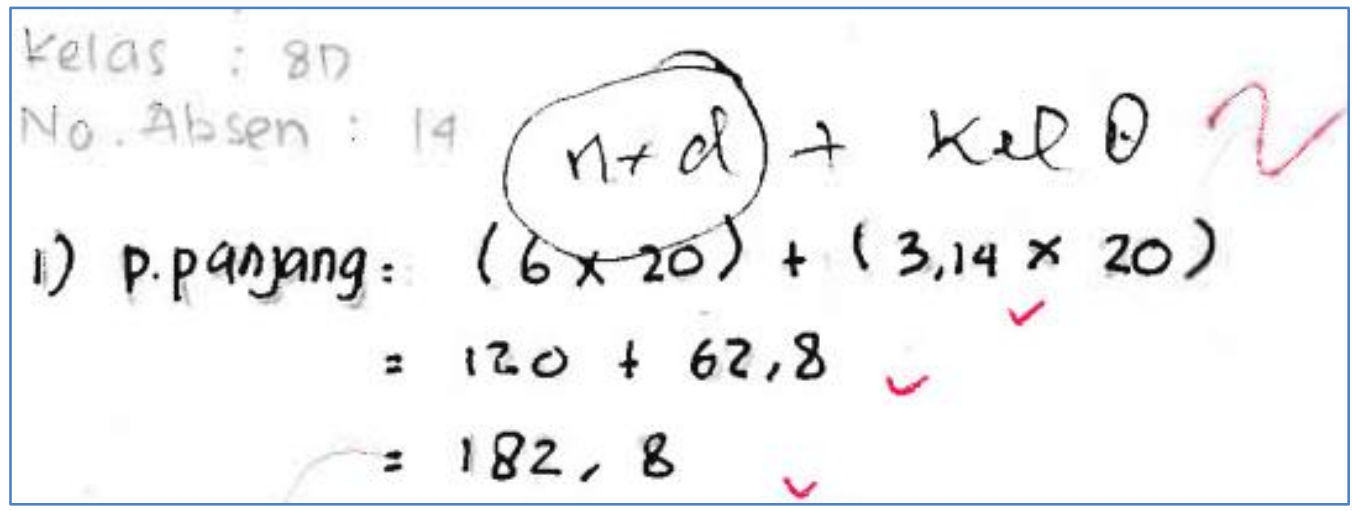

Figure 5. Representation of fikri mathematics to solve problem 1

Interviewer : Have you ever been given the same question like this before?

Fikri :I think I have

Interviewer : Then, What have you still remember?

Fikri : Forget

Interviewer : How did the question look like?

Fikri : Not remember

Interviewer : The, Can you solve this problem, how?

Fikri : Remember the formula that was given on the test only

Interviewer : See! You ever got a question like this before in a course. How did the question look like?

Fikri : Forget again

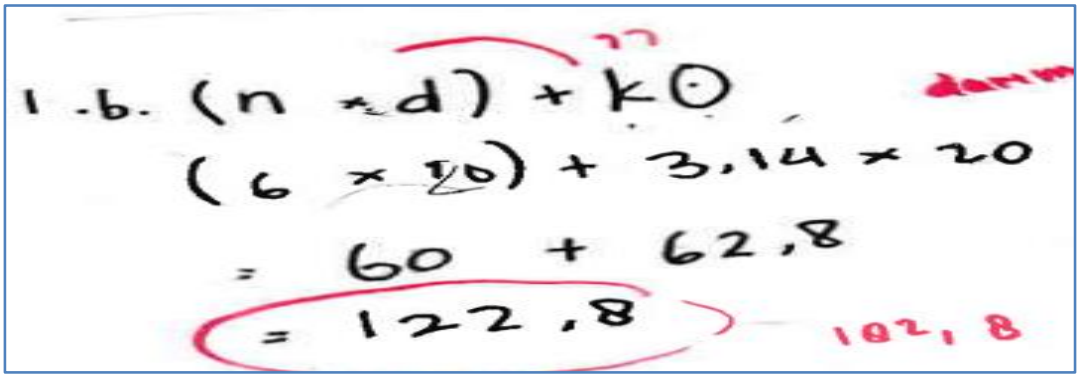

Figure 6. Representation of dhea mathematics for problem one 


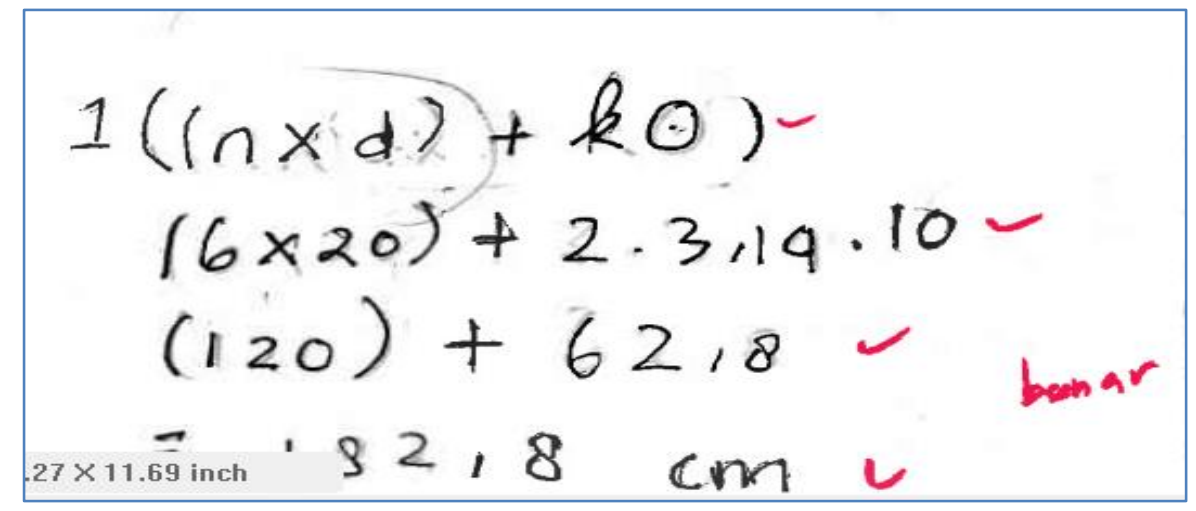

Figure 7. Representation of annisa mathematics for problem one

Interviewer : Have you ever been given the same question like this before?

Dhea :Yes, I have

Interviewer : What have you remembered then?

Dhea : At the moment if I am not mistaken that there were 4 circles given

Interviewer : How did the ropes look like?

Dhea : Like a square, but there are six ropes in this question. At that time, the teacher gave the question where there 4 circles

Interviewer : So, how to do this? What was connected at that time?

Dhea : The formula $n \times d+$, circumference may be at that time there were four circles, so the formula was $4 x d$, now there are six circles; thus, the formula changes by $6 x d$. The principle is the same depending on how many ropes there are.

Interviewer : Do you know or not why it is like that when the ropes are connected on the pipes? Can you show me what the six ropes are?

Dhea : Which one? I do not know

Interviewer : Please point which ones the ropes are!

Dhea : I don't know, I want to use this formula

Interviewer : All right

Here is the description of Annisa interview

Interviewer : had you been given a problem like this before?

Annisa : Yes, I had

Interviewer : What did you remember?

Annisa : At that time the circle was less, there were four if I was not wrong

Interviewer : What kind of shape was its bond?

Annisa : like a first, there were four circle

Interviewer : so could you finish it, how? Were you linked with that time or not?

Annisa : Stay replaced $n x d$ at that time being $4 x d$, and now replaced $6 x d$, the principle was like this.

Interviewer : Do know what the reason was why It could be changed?

Annisa $\quad:$ I did not know, and it depended on many circles, didn't it? If the circle was 4, $n$ was replaced 4 , if there were six, just replaced 6 . Because in what book teacher once said it, $n$ it was the number of circles. It was not so, was it?

Interviewer : Yes, like that if we remember the formula, just changed. However, understanding the principle why can be like that? Trying to connect to its strap 
Annisa : was it a picture of four? (Trying to redraw a bond form with four-pipe)

Interviewer :Yes, what was the relationship with the diameter?

Annisa : Oh, this meant, it was a rope which was here a diameter or two fingers. This one, this one, and this one (while tracing with the pen). So, there is four. If there were six diameters (trace again by using a pen)

Interviewer : Yes, good

This documentation was presented when Annisa tried to analyze the relationship between previous knowledge with new problems not only based on external features but also more to the mathematical structure through the direction of the interviewer.

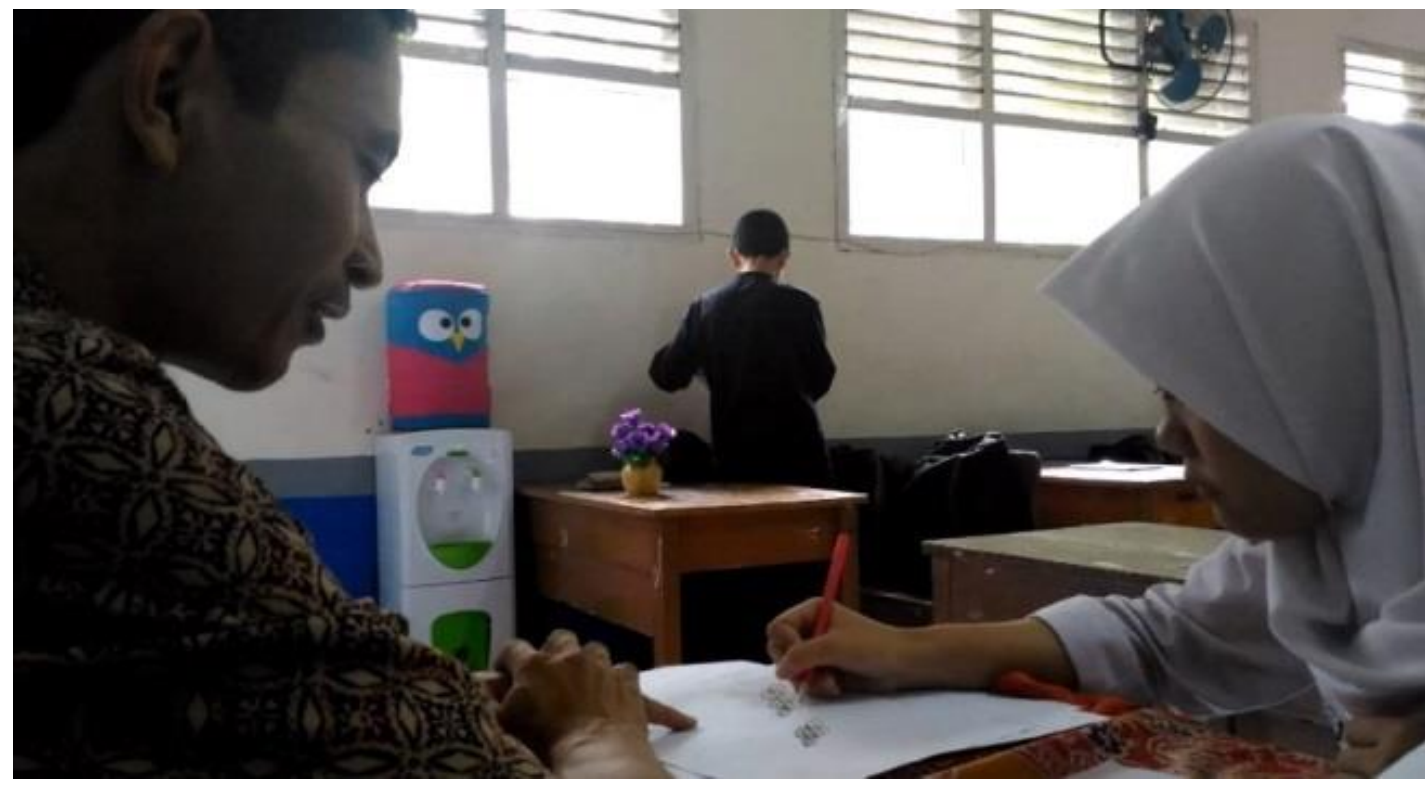

Figure 8. Annisa described rope with four paralon and six paralon

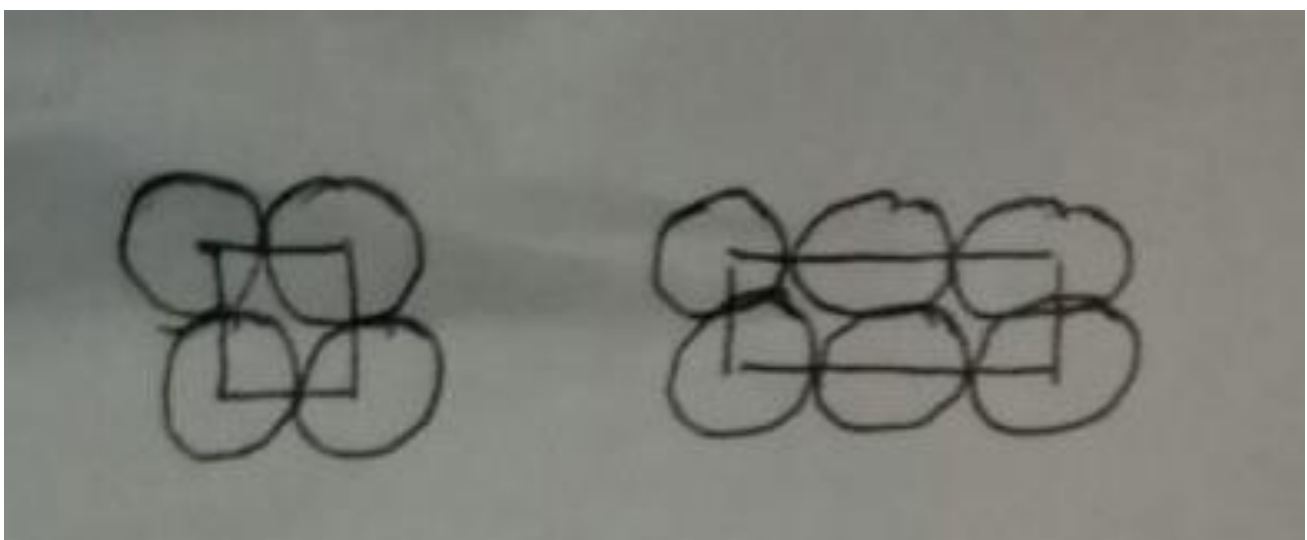

Figure 9. Annisa representation in figure

Initially, both of students could identify the same problems that had been resolved, but not on the mathematical structure, but only on the external features by remembering the formula and associating it with the number of circles. The difference was that Annisa could be directed to relate by looking at its mathematical structure while Dhea insisted on using 
the previously thought formulas. Based on Figure 8 and Figure 9, Annisa tried to redefine and identify the mathematical structure based on the interviewer's direction.

Based on the explanation, Dhea had exceeded the behavioural categories shown by Fikri. Fikri could not use previously problems that had resolved, whereas Dhea could identify similar problems, but not its mathematical structure (only on external features) and could not be directed to identify similar problems according to its mathematical structure, while Annisa initially could only identify similar problems with out-of-trouble features, but could be directed to identify similar problems according to their mathematical structure.

Furthermore, Alvaro could identify a similar problem but not remember the formula and immediately looked to the diameter and radius on the pipe binding strap. Alvaro identified a similar problem according to the mathematical structure, not on external features only. Here were answers (see Figure 10) and interviews to Alvaro in a row.

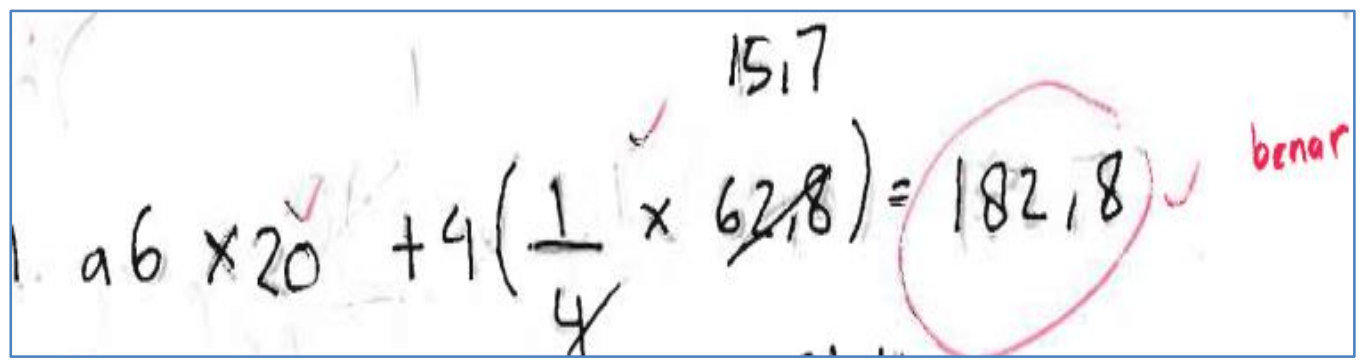

Figure 10. Alvaro's mathematical representation for problem one

Interviewer : Had you ever been given this question before?

Alvaro :I thought I had

Interviewer : So, what did you remember?

Alvaro : It was simple then; these were four circles, the same principle. This was the shorter string, here was only one diameter in length, if six into two diameters were here (pointing at the picture)

Interviewer : Did not use a form to complete it?

Alvaro $\quad:$ I did not remember the formula. Just the principle, it was just counting this string and see how much diameter.

Based on the interview, Alvaro did not remember and did not use the formula. Alvaro connected the length of the strap on the pipe with the diameter of the circle. It can be inferred that Alvaro had identified a similar problem based on his mathematical structure, not merely identifying based on external features only.

\subsubsection{Many ways were used in mathematical problem solving}

Based on the interview, Alvaro did not remember and did not use the formula. However, connected the length of the strap on the pipe with the diameter of the circle. It can be inferred that Alvaro had identified a similar problem based on his mathematical structure, not merely identifying based on external features only.

Furthermore, Fikri and Annisa have shown several variations in how to solve all problems given Fikri has used various strategies in solving all problems but has not wanted to find another way or the right way to solve the problem. Therefore, Fikri is categorized who have a routine orientation to the variety of strategies in problem-solving. Annisa differently shows this; Annisa also has a variety of ways in solving the seven problems given. 
Annisa has shown variations in how to solve problems such as drawing and using logic. Unlike Fikri Annisa, she wants to find a variety of other ways to solve problems.

Students categorized as sophisticated classified by Muir et al. (2008), which have an orientation to behaviour able to identify other ways of solving all problems shown by Alvaro's behaviour. For each problem given, from several presentations, Alvaro tends to have other ways of solving problems from other students. Alvaro has his strategy in problemsolving, without remembering systematic formulas as demonstrated by the previous behaviour of Fikri and Annisa.

\subsubsection{Written and Verbal Communication in Mathematical Problem Solving}

Students who behave apathetic tend to show inadequate verbal and written communication. Dhea has shown this behaviour from the answers given that it appears that Dhea's written communication is inadequate. When interviewed about the answers obtained by Dhea also cannot explain these answers.

Furthermore, the characteristics displayed by routine students are unclearly written communication but can be clarified through verbal communication. Annisa's behavior shows this, but Annisa does not want to clarify the written language she has made even though the interviewer has directed it.

Alvaro showed the same thing. Alvaro shows behaviour when communicating written language is unclear and can be explained through verbal language, but has a difference with Annisa, that is when directed by the interviewer, Alvaro has a desire to clarify the language of his writing. When confirmed about the answer given, Alvaro can explain it well.

Based on the analysis of the three students, it can be concluded that: Dhea showed unclearness in both written and verbal language, Anissa showed written language that was unclear but could clarify verbal language, and there was no desire to clarify the language of his writing, Alvaro in resolving problem four showed lack of clarity in the written language but can clarify the verbal language and have an effort (desire) to clarify the written language, furthermore for the problem of the two written and verbal languages Alvaro is adequate and clear.

\subsection{Control}

Things that are considered in the aspect of self-control (control) is how students think metacognitive looks or not in written or verbal communication. The characteristics of student behaviour oriented toward apathy are metacognitive thinking does not appear both in writing and verbally. Fikri's behaviour indicates this in solving problem two. Fikri's metacognitive thinking does not appear in writing, because Fikri's answers have neat (smooth) characteristics, without scribbles, and are wrong. When answering Fikri also often answers fast but wrong.

The orientation of Dhea behavior shows different things. Dhea has a metacognitive thinking orientation behaviour that does not appear in writing, but metacognitive appears verbally but cannot be directed to perform metacognitive processes on written answers. Furthermore, Annisa also shows metacognitive thinking in writing and shown in verbal language, and metacognitive thinking can be directed to the writing or answers made.

Alvaro shows the orientation of sophisticated behavior. Alvaro shows the metacognitive processes appear in written and verbal. Alvaro has also shown the process of obtaining the beam elements correctly, so it can be said that Alvaro's written answers are neat, clear and true meaning the metacognitive process appears in writing. From the results of the interview, Alvaro was very careful and rethought what he had done. Alvaro said he 
had calculated many times. Alvaro is always rethinking about the way he had thought before. So, Alvaro can already be categorized in the advanced category in the aspect of self-control (control).

\subsection{Confidence}

\subsubsection{Confidence in How to Implement Strategies in Mathematical Problem Solving}

In this indicator, Muir et al. (2008) categorizes students behaving apathetic by doing the same strategy because they lack confidence in their ability to solve the problem strategies used, students, regularly behaving routine implementing strategies and students who sophisticated can produce their strategies because they have high confidence in the use of problem-solving strategies. Furthermore, students with sophisticated categories produce their strategies. Alvaro did not use a systematic formula in solving problems as Dhea and Annisa did, but Alvaro found his strategy in solving the given problem.

\subsubsection{Confidence in the variety of strategies used in solving mathematical problems}

Based on the findings of this indicator, there are four behavioural category orientations. Students in the apathetic category lean on one strategy. Apathetic students tend always to use strategies to manipulate numbers in the problem. Fikri often shows this behaviour although, in some indicators, they are classified as routine categories. When interviewed, they often answered that they did not understand the problem if directed, they tended to answer with answers that did not know.

In students who are categorized routinely, tend to rely on more than two strategies, when one strategy does not work, he does not turn to another strategy. This behaviour is often shown, Lutfi answered knowing more than one strategy, but when a solution was not found, he did not turn to another strategy. Lutfi, when directed by the interviewer to use strategies that lead to solutions, tend to reject and can not do it. Furthermore, Dhea leaned and knew more than two strategies; when one strategy did not work, he did not switch to another strategy but could be directed to switch strategies. Alvaro has combined several strategies, as in the case of two Alvaro has already described, then imagined and used a guess and check strategy.

\subsection{Affective}

In the affective aspects of the indicator seen is how students' confidence in solving problems. Confidence is observed when students answer questions from the interviewer. During interviews, students who behave apathetically often do not think in advance what they say. Apathetic students' confidence is in line with the quick answers they express. Dyvi and Fikri are students who exhibit this behaviour.

In other cases, Dhea and Annisa often show a lack of confidence in answering interviewer questions. Although both have the behaviour of a lack of confidence in solving problems, there are differences between Dhea and Annisa. Dhea often expressed a lack of confidence in solving problems but did not want to explore further ways of solving them. On the other hand, Annisa showed the same lack of confidence as Dhea but wanted to explore further the solution. In another case, Alvaro showed confidence in his ability to solve problems. Almost all problems Alvaro answers confidently and correctly. Alvaro can be categorized as sophisticated behaviour in the aspect of self-confidence, although Alvaro cannot solve all the problems given correctly. 
Based on the description of the findings, Muir et al. (2008) had categorized student behaviour into three categories: naiff, routine, and sophisticated that was not yet fully drawing the behaviour of the eighteen observed students. Category of routine students, there were two different orientations: there were students who could be directed, and there were students who could not be directed to the orientation of students behave sophisticated. The conclusion of the analysis of student orientation findings on routine categories could be classified into two categories: routine and semi-advanced. The orientation of these behaviours will be described in Table 6 .

Table 6. Description of student behavior at the junior high school level

\begin{tabular}{|c|c|c|c|c|c|c|}
\hline \multirow[b]{2}{*}{ No } & \multirow[b]{2}{*}{ Factor } & \multirow{2}{*}{ Indicator } & \multicolumn{4}{|c|}{ Category Of Behavior } \\
\hline & & & Apathetic & Routine & $\begin{array}{c}\text { Semi } \\
\text { Sophisticated }\end{array}$ & Sophisticated \\
\hline \multirow[t]{3}{*}{1} & $\begin{array}{l}\text { Knowledge } \\
\text { Ownership }\end{array}$ & $\begin{array}{l}\text { The } \\
\text { application } \\
\text { of Polya's } \\
\text { heuristic } \\
\text { steps in } \\
\text { mathematic } \\
\text { al problem } \\
\text { solving }\end{array}$ & $\begin{array}{l}\text { Made a } \\
\text { mistake on } \\
\text { the four } \\
\text { solving steps }\end{array}$ & $\begin{array}{l}\text { No effort to } \\
\text { verify the } \\
\text { solution } \\
\text { (Make a } \\
\text { mistake on } \\
\text { some } \\
\text { troubleshoot } \\
\text { ing steps) }\end{array}$ & $\begin{array}{l}\text { There is an } \\
\text { attempt at } \\
\text { verifying the } \\
\text { solution but still } \\
\text { making mistakes } \\
\text { on some } \\
\text { troubleshooting } \\
\text { steps }\end{array}$ & $\begin{array}{l}\text { A high score on } \\
\text { each } \\
\text { troubleshooting } \\
\text { step }\end{array}$ \\
\hline & & $\begin{array}{l}\text { The use of } \\
\text { prior } \\
\text { knowledge } \\
\text { for } \\
\text { mathematic } \\
\text { al problem } \\
\text { solving }\end{array}$ & $\begin{array}{l}\text { Cannot use } \\
\text { previously } \\
\text { resolved } \\
\text { issues }\end{array}$ & $\begin{array}{l}\text { Can identify } \\
\text { a similar } \\
\text { problem, } \\
\text { but not on } \\
\text { the } \\
\text { mathematic } \\
\text { al structure } \\
\text { (can identify } \\
\text { similar } \\
\text { problems } \\
\text { only on } \\
\text { external } \\
\text { features } \\
\text { only) }\end{array}$ & $\begin{array}{l}\text { Can identify a } \\
\text { similar problem, } \\
\text { but not on the } \\
\text { mathematical } \\
\text { structure, but can } \\
\text { be directed to } \\
\text { look at problems } \\
\text { in the } \\
\text { mathematical } \\
\text { structure }\end{array}$ & $\begin{array}{l}\text { Identify similar } \\
\text { problems } \\
\text { according to the } \\
\text { mathematical } \\
\text { structure } \\
\text { his }\end{array}$ \\
\hline & & $\begin{array}{l}\text { Many ways } \\
\text { are used in } \\
\text { mathematic } \\
\text { al problem } \\
\text { solving }\end{array}$ & $\begin{array}{l}\text { Often use the } \\
\text { same way to } \\
\text { solve all } \\
\text { problems } \\
\text { because of the } \\
\text { limitations of } \\
\text { knowledge } \\
\text { possessed }\end{array}$ & $\begin{array}{l}\text { Focus on } \\
\text { one way } \\
\text { with the } \\
\text { knowledge } \\
\text { you have to } \\
\text { solve a } \\
\text { particular } \\
\text { problem, } \\
\text { but have no } \\
\text { desire to } \\
\text { generate the } \\
\text { right way to } \\
\text { solve the } \\
\text { problem }\end{array}$ & $\begin{array}{l}\text { Focus on one } \\
\text { way with the } \\
\text { knowledge you } \\
\text { have to solve a } \\
\text { particular } \\
\text { problem, but } \\
\text { have a desire to } \\
\text { generate the right } \\
\text { way to solve the } \\
\text { problem }\end{array}$ & $\begin{array}{l}\text { Identify other } \\
\text { ways of } \\
\text { troubleshooting }\end{array}$ \\
\hline
\end{tabular}




\begin{tabular}{|c|c|c|c|c|c|c|}
\hline \multirow[b]{2}{*}{ No } & \multirow[b]{2}{*}{ Factor } & \multirow{2}{*}{ Indicator } & \multicolumn{4}{|c|}{ Category Of Behavior } \\
\hline & & & Apathetic & Routine & $\begin{array}{c}\text { Semi } \\
\text { Sophisticated }\end{array}$ & Sophisticated \\
\hline & & $\begin{array}{l}\text { Written and } \\
\text { verbal } \\
\text { communicat } \\
\text { ion in } \\
\text { mathematic } \\
\text { al problem } \\
\text { solving }\end{array}$ & $\begin{array}{l}\text { Written and } \\
\text { verbal } \\
\text { communicatio } \\
\mathrm{n} \text { is } \\
\text { inadequate }\end{array}$ & $\begin{array}{l}\text { Written } \\
\text { communicat } \\
\text { ion is not } \\
\text { clear, but } \\
\text { can clarify } \\
\text { through } \\
\text { verbal } \\
\text { communicat } \\
\text { ion }\end{array}$ & $\begin{array}{l}\text { Written } \\
\text { communication is } \\
\text { not clear, but can } \\
\text { clarify through } \\
\text { verbal } \\
\text { communication } \\
\text { and can be } \\
\text { directed to clarify } \\
\text { his written } \\
\text { communication }\end{array}$ & $\begin{array}{l}\text { Written and } \\
\text { verbal } \\
\text { communication is } \\
\text { sufficient } \\
\text { (obviously) }\end{array}$ \\
\hline 2 & $\begin{array}{l}\text { Self Control } \\
\text { (Control) }\end{array}$ & $\begin{array}{l}\text { Thinking } \\
\text { metacogniti } \\
\text { on in } \\
\text { mathematic } \\
\text { al problem } \\
\text { solving } \\
\text { communicat } \\
\text { ion }\end{array}$ & $\begin{array}{l}\text { Thinking } \\
\text { metacognition } \\
\text { is invisible, } \\
\text { both in } \\
\text { written and } \\
\text { verbal }\end{array}$ & $\begin{array}{l}\text { Metacogniti } \\
\text { on does not } \\
\text { appear in } \\
\text { writing, but } \\
\text { metacogniti } \\
\text { on appears } \\
\text { verbally }\end{array}$ & $\begin{array}{l}\text { Metacognition is } \\
\text { not without } \\
\text { writing, but } \\
\text { metacognition } \\
\text { appears verbally } \\
\text { and can be } \\
\text { directed to } \\
\text { perform } \\
\text { metacognition } \\
\text { processes in } \\
\text { written answers }\end{array}$ & $\begin{array}{l}\text { Thinking } \\
\text { metacognition } \\
\text { appears in written } \\
\text { and verbal } \\
\text { responses }\end{array}$ \\
\hline \multirow[t]{2}{*}{3} & Confidence & $\begin{array}{l}\text { Confidence } \\
\text { in how to } \\
\text { implement } \\
\text { the strategy } \\
\text { in problem- } \\
\text { solving }\end{array}$ & $\begin{array}{l}\text { Doing exactly } \\
\text { the same } \\
\text { strategy }\end{array}$ & $\begin{array}{l}\text { Implementi } \\
\text { ng the } \\
\text { strategy in a } \\
\text { systematic } \\
\text { way }\end{array}$ & $\begin{array}{l}\text { Implementing the } \\
\text { strategy in a } \\
\text { systematic, yet } \\
\text { expandable way } \\
\text { to generate its } \\
\text { strategy }\end{array}$ & $\begin{array}{l}\text { Strategy } \\
\text { mathematics } \\
\text { Generate your } \\
\text { own }\end{array}$ \\
\hline & & $\begin{array}{l}\text { Confidence } \\
\text { in the } \\
\text { variety of } \\
\text { strategies } \\
\text { used in } \\
\text { mathematic } \\
\text { al problem } \\
\text { solving } \\
\text { strategy }\end{array}$ & $\begin{array}{l}\text { Rely on one } \\
\text { strategy }\end{array}$ & $\begin{array}{l}\text { Relying on } \\
\text { more than } \\
\text { two } \\
\text { strategies, } \\
\text { when one } \\
\text { strategy } \\
\text { does not } \\
\text { work does } \\
\text { not switch } \\
\text { to another }\end{array}$ & $\begin{array}{l}\text { Relying on more } \\
\text { than two } \\
\text { strategies, when } \\
\text { one strategy does } \\
\text { not work, does } \\
\text { not switch to } \\
\text { another strategy, } \\
\text { and can be } \\
\text { directed to move } \\
\text { strategy }\end{array}$ & $\begin{array}{l}\text { Desiring to } \\
\text { combine several } \\
\text { strategies }\end{array}$ \\
\hline 4 & Affective & $\begin{array}{l}\text { Often } \\
\text { declare lack } \\
\text { of } \\
\text { confidence } \\
\text { in solving } \\
\text { problems, } \\
\text { but desire to } \\
\text { explore } \\
\text { further how } \\
\text { to solve } \\
\text { them with } \\
\text { confidence }\end{array}$ & $\begin{array}{l}\text { Confidence in } \\
\text { solving } \\
\text { mathematical } \\
\text { problems }\end{array}$ & $\begin{array}{l}\text { Confidence } \\
\text { is in line } \\
\text { with the } \\
\text { quick } \\
\text { answer }\end{array}$ & $\begin{array}{l}\text { Often declare } \\
\text { lack of } \\
\text { confidence in } \\
\text { solving problems }\end{array}$ & $\begin{array}{l}\text { Appears } \\
\text { confident in } \\
\text { problem-solving } \\
\text { skills }\end{array}$ \\
\hline
\end{tabular}


The results of this study try to discover the behaviour presented by eighteen students of junior high school. After analyzing the work and constructing the video of each student's interview results, it was obtained four students' behaviour orientations in problem-solving. Muir et al. (2008) had studied the consistency of students' behaviour in previous problemsolving, which classified three student orientations in problem-solving, including naive, routine, and sophisticated. This paper completes the behavioural orientation found by Muir et al. (2008) while solving the problems, in which these three orientations were not considered to cover the whole behaviour shown by the eighteen students of junior high school.

Two types of routine problem-solvers were found in this study in which there are both routine troubleshooters who have a high curiosity about solutions of the problem solving and routine troubleshooters who were not interested in exploring further issues. Category of problem solvers in this paper is grouped into four groups, namely: ignorant, routine, semi-sophisticated and sophisticated. The results of this behavioural analysis can be used as a reference to teachers to make decisions in implementing what instruction decisions are appropriate for the students to behave sophistically in solving problems.

This research also aims to investigate the behaviour to make some assumptions to what extent students can solve the problems. According to Malloy and Jones (1998), the assessment of the behaviour of children could see the irregularities and consider the investigation for the assumptions we have towards students. He conducted and investigated the problem-solving skills of 24 African students, and he thought that his research results did not make the reader agree to lower expectations for African students. According to Molloy, the results of this study could be used for teachers to take the next step to improve classroom learning practices.

\section{CONCLUSION}

Category of problem solvers in this paper is grouped into four groups, namely: ignorant, routine, semi-sophisticated and sophisticated. This article can also be used for a reference to reflect, investigate, and diagnose to what extent the children behave and contribute to problem-solving questions so that teachers should determine appropriate leading strategies and methods. In this study, it also shows that aspects affecting the students' success in problem-solving are not only aspects of knowledge ownership but also aspects of metacognitive, control, self-confidence. His research showed that students in certain contexts "learners with good metacognitive ability" exhibited better academic achievement. Revealed Smith (2013). This article describes how children who have metacognitive abilities and care about errors in problem-solving adding their reflexes to the solutions they produce. In the other hand, this also aims to communicate and collect the most important arguments espousing problem-solving in applying for math, especially on space geometry lesson to junior high school' students. For further research, it is expected to look at the consistency of problem-solving behaviour by using plentiful junior high schools as a sample and can be performed in diverse topics and materials.

\section{REFERENCES}

Cai, J. (2003). Singaporean students' mathematical thinking in problem solving and problem posing: an exploratory study. International journal of mathematical education in science and technology, 34(5),

719-737. https://doi.org/10.1080/00207390310001595401 
Chew, M. S. F., Shahrill, M., \& Li, H. C. (2019). The integration of a problem-solving framework for Brunei high school mathematics curriculum in increasing student's affective competency. Journal on Mathematics Education, 10(2), 215-228. https://doi.org/10.22342/jme.10.2.7265.215-228

De Hoyos, M., Gray, E., \& Simpson, A. (2002). Students assumptions during problem solving. In 2nd International Conference on the Teaching of Mathematics, Crete, Greece.

Ekawati, R., Susanti, S., \& Chen, J. C. (2020). Primary students' mathematical literacy: A case study. Infinity Journal, 9(1), 49-58. https://doi.org/10.22460/infinity.v9i1.p4958

Elia, I., van den Heuvel-Panhuizen, M., \& Kolovou, A. (2009). Exploring strategy use and strategy flexibility in non-routine problem solving by primary school high achievers in mathematics. ZDM , 41(5), 605-618. https://doi.org/10.1007/s11858-009-0184-6

Fitzpatrick, C. (1994). Adolescent mathematical problem solving: The role of metacognition, strategies and beliefs. Paper Presented at the Annual Meeting of the American Educational Research Association, New Orleans, LA.

Harisman, Y., Kusumah, Y. S., Kusnandi, K., \& Noto, M. S. (2019). The teachers' experience background and their profesionalism. Infinity Journal, 8(2), 129-142. https://doi.org/10.22460/infinity.v8i2.p129-142

Harisman, Y., Noto, M. S., Bakar, M. T., \& Amam, A. (2017). The different patterns of gesture between genders in mathematical problem solving of geometry. Journal of Physics: Conference Series, 812(1), 012039. https://doi.org/10.1088/17426596/812/1/012039

Harisman, Y., Noto, M. S., \& Hidayat, W. (2020). Experience student background and their behavior in problem solving. Infinity Journal, 9(1), 59-68. https://doi.org/10.22460/infinity.v9i1.p59-68

Hendriana, H., \& Fadhillah, F. M. (2019). The students' mathematical creative thinking ability of junior high school through problem-solving approach. Infinity Journal, 8(1), 11-20. https://doi.org/10.22460/infinity.v8i1.p11-20

Hidayat, W. (2017). Adversity quotient dan penalaran kreatif matematis siswa sma dalam pembelajaran argument driven inquiry pada materi turunan fungsi. KALAMATIKA: Jurnal Pendidikan Matematika, 2(1), 15-28. https://doi.org/10.22236/KALAMATIKA.vol2no1.2017pp15-28

Hutajulu, M., Wijaya, T. T., \& Hidayat, W. (2019). The effect of mathematical disposition and learning motivation on problem solving: An analysis. Infinity Journal, 8(2), 229238. https://doi.org/10.22460/infinity.v8i2.p229-238

Kariadinata, R. (2021). Students' reflective abstraction ability on linear algebra problem solving and relationship with prerequisite knowledge. Infinity Journal, 10(1), 1-16. https://doi.org/10.22460/infinity.v10i1.p1-16

Lester, F., \& Kroll, D. (1993). Assessing student growth in mathematical problem solving. In G. Kulm (Ed.). Assessing higher order thinking in mathematics (pp. 53-70). Washington, DC: American Association for the Advancement of Science. 
Malloy, C. E., \& Jones, M. G. (1998). An investigation of African American students' mathematical problem solving. Journal for Research in Mathematics Education, 29(2), 143-163. https://doi.org/10.5951/jresematheduc.29.2.0143

Maulidia, F., Johar, R., \& Andariah, A. (2019). A case study of students'creativity in solving mathematical problems through problem based learning. Infinity Journal, 8(1), 1-10. https://doi.org/10.22460/infinity.v8i1.p1-10

McLeod, D. B. (1988). Affective issues in mathematical problem solving: Some theoretical considerations. Journal for Research in Mathematics Education, 19(2), 134-141. https://doi.org/10.5951/jresematheduc.19.2.0134

Ministry of Education and Culture of the Republic Indonesia [MECRI]. (2016). Peraturan menteri pendidikan dan kebudayaan republik Indonesia nomor 22 tahun 2016 tentang standar proses pendidikan dasar dan menengah. Jakarta: Kementerian Pendidikan dan Kebudayaan Republik Indonesia.

Muir, T., Beswick, K., \& Williamson, J. (2008). "I'm not very good at solving problems": An exploration of students' problem solving behaviours. The Journal of Mathematical https://doi.org/10.1016/j.jmathb.2008.04.003

Olivares, D., Lupiáñez, J. L., \& Segovia, I. (2021). Roles and characteristics of problem solving in the mathematics curriculum: a review. International Journal of Mathematical Education in Science and Technology,52(7), 1079-1096. https://doi.org/10.1080/0020739X.2020.1738579

Polya, G. (1957). How to solve it (2nd ed.). New Jersey: Princeton University Press.

Praekhaow, P., Chindanurak, T., Konglok, S. A., \& Sokhuma, K. (2021). Studying conditions and problems for developing mathematics learning model of undergraduate students in Thailand. Infinity Journal, 10(1), 121-132. https://doi.org/10.22460/infinity.v10i1.p121-132

Schoenfeld, A. H. (1982). Measures of problem-solving performance and of problemsolving instruction. Journal for Research in Mathematics Education, 13(1), 31-49. https://doi.org/10.5951/jresematheduc.13.1.0031

Smith, M. J. (2013). An exploration of metacognition and its effect on mathematical performance in differential equations. Journal of the Scholarship of Teaching and Learning, 13(1), 100-111.

Stacey, K. (2005). The place of problem solving in contemporary mathematics curriculum documents. The Journal of Mathematical Behavior,24(3-4), 341-350. https://doi.org/10.1016/j.jmathb.2005.09.004

Sulak, S. (2010). Effect of problem solving strategies on problem solving achievement in primary school mathematics. Procedia-Social and Behavioral Sciences, 9, 468-472. https://doi.org/10.1016/j.sbspro.2010.12.182 